\title{
Long work hours, hypertension, and cardiovascular disease
}

\author{
Jornadas de trabalho longas, hipertensão \\ e doença cardiovascular
}

\author{
1 Department of Community \\ and Preventive Medicine, \\ Mount Sinai School of \\ Medicine, New York, USA.

\section{Correspondence} \\ P. Landsbergis \\ Department of Community \\ and Preventive Medicine, \\ Mount Sinai School \\ of Medicine. Box 1043, \\ One Gustave Levy Place, \\ New York, NY \\ 10029-6574, USA. \\ paul.landsbergis@mssm.edu
}

\begin{abstract}
Several studies of myocardial infarction and two studies of blood pressure have shown associations with long work hours (greater than 5560 hours per week). However, the number of studies of long work hours with cardiovascular outcomes is limited, and further research is needed to better understand the mechanisms and moderating factors.
\end{abstract}

Work Hours; Hypertension; Occupational Health; Chronobiology
Paul Landsbergis 1

There have been four recent comprehensive reviews of the growing literature on long work hours (overtime work) and a wide variety of health effects, including work accidents and injuries, musculoskeletal disorders, fatigue, psychological symptoms, health behaviors, and cardiovascular risk factors and disease 1,2,3,4. A number of recent studies have examined the possible impact of long work hours on blood pressure, risk of hypertension, and cardiovascular disease. Most of these studies were conducted in Japan, where long work hours have become increasingly common and where death from overwork, known as karoshi, is a publicly recognized phenomenon, despite limited epidemiological evidence 5 .

\section{Blood pressure elevation and hypertension}

Two Japanese studies found evidence linking overtime work and blood pressure among men working greater than 55 hours per week. Iwasaki et al. 6 found significantly elevated systolic blood pressure among salesmen aged 50-60 years whose combined commute and work hours exceeded 61 hours per week as compared to those working 57 hours or less. However, no blood pressure differences were reported in younger workers. Hayashi et al. 7 observed higher blood pressure in a group of white-collar 
employees working more than 60 hours of overtime per month as compared to those working less than 30 hours overtime per month. In addition, Hayashi et al. 7 found that within another group of white-collar workers followed longitudinally, their blood pressure was significantly higher and their sleep hours significantly lower when working more overtime (average 96 hours/month) as compared to a "control" period (average 43 hours/month of overtime). In contrast, Nakanishi et al. 8 found that whitecollar workers reporting 10 or more hours of work per day had a lower risk for developing hypertension when compared with workers reporting less than eight hours of work per day. In addition, Park et al. 9 reported no correlation between blood pressure and work hours in Korean engineers whose work hours during the previous month ranged from an average of 52 hours to 89 hours per week.

It should be noted that only the study by Hayashi et al. 7 measured blood pressure by averaging multiple readings at work using ambulatory monitoring methods. Ambulatory blood pressure is considered a more reliable and valid measure of a person's true blood pressure than single readings taken in a clinic because of the increased number of readings, the lack of observer bias, and the fact that readings are taken during normal daily activities 10,11.

\section{Cardiovascular disease}

A number of studies, beginning in 1958, have suggested that long working hours may increase risk of heart disease $12,13,14,15$. Two recent Japanese studies found an association between long work hours and first heart attack in men. Liu et al. 16 found a twofold increase in risk for weekly work hours greater than 60 compared to less than or equal to 40 hours per week. They also found that less than or equal to five hours of sleep per day and frequent lack of sleep (two or more days per week with less than five hours of sleep) were also associated with a 2-3 fold increased risk. Sokejima et al. 17 found an increased risk for either short (less than 7) or long (greater than 11) daily hours of work in the previous month (the authors speculated that the group with shorter work hours may have been manifesting early symptoms of disease.) In addition, the authors found a significant trend of increasing risk of heart attack with a change towards increasing working hours in the year prior to a heart attack.

Only one 18 of two 8,18 Japanese studies found an association between work hours and adult onset diabetes.

\section{Mechanisms and moderating factors}

The review articles cited earlier suggest that overtime may act directly as a stressor, may act to increase exposure to other workplace hazards, or may promote unhealthy behaviors. In general, being at work (versus not being at work) increases blood pressure, so that working longer hours implies more time with higher blood pressure 5. Inconsistent associations have been observed between long work hours and cigarette smoking, alcohol use, and physical exercise 1,3 .

Overtime has also been associated with fatigue and shorter sleep hours 3,5,7,19. Insufficient sleep can increase the activity of the sympathetic nervous system, heart rate, and blood pressure, and may be an important pathway connecting long work hours and cardiovascular disease. Sleep hours of less than six hours/day are associated with an increased risk of heart disease compared with normal sleep hours (78 hours/day) 16,19.

The impact of overtime on health may be greater for workers in stressful jobs, such as professional drivers 20 , workers with poor social relations 21 , and shift workers 4 . The health risks of overtime work may also be greater for older workers 2,6, women workers, especially if domestic work hours are also considered 2 , and workers facing mandatory overtime 2 . However, such interaction effects have rarely been assessed in studies of hypertension and cardiovascular disease.

In summary, while there is evidence linking long work hours to fatigue, fewer sleep hours, blood pressure elevation, and cardiovascular disease, the number of studies of cardiovascular outcomes is limited, and further research is needed. 


\section{Resumo}

Diversos estudos sobre o infarto do miocárdio e dois estudos sobre pressão arterial mostraram associações com longas jornadas de trabalho (superiores a 55-60 horas por semana). No entanto, o número de investigações sobre longas jornadas com desfechos na área cardiovascular é limitado, sendo necessários novos estudos que levem ao melhor conhecimento dos mecanismos e dos fatores moderadores.

Jornada de Trabalho; Hipertensão; Saúde Ocupacional; Cronobiologia

\section{References}

1. Spurgeon A, Harrington JM, Cooper CL. Health and safety problems associated with long working hours: a review of the current position. Occup Environ Med 1997; 54:367-75.

2. Sparks K, Cooper C, Fried Y, Shirom A. The effects of hours of work on health: a meta-analytic review. Journal of Occupational and Organizational Psychology 1997; 70:391-408.

3. van der Hulst M. Long work hours and health. Scand J Work Environ Health 2003; 29:171-88.

4. Caruso C, Hitchcock E, Dick R, Russo J, Schmit J. Overtime and extended work shifts: Recent findings on illnesses, injuries, and health behaviors. Cincinnati: National Institute for Occupational Safety and Health; 2004.

5. Steenland K. Shift work, long hours, and CVD: a review. Occupational Medicine: State-of-the-Art Reviews 2000; 15:7-17.

6. Iwasaki K, Sasaki T, Oka T, Hisanaga N. Effect of working hours on biological functions related to cardiovascular system among salesmen in a machinery manufacturing company. Ind Health 1998; 36:361-7.

7. Hayashi T, Kobayashi Y, Yamaoka K, Yano E. Effect of overtime work on 24-hour ambulatory blood pressure. J Occup Environ Med 1996; 38:1007-11.

8. Nakanishi N, Yoshida H, Nagano K, Kawashimo $\mathrm{H}$, Nakamura K, Tatara K. Long working hours and risk for hypertension in Japanese male white collar workers. J Epidemiol Community Health 2001; 55:316-22.

9. Park J, Kim Y, Cho Y, Woo K, Chung H, Iwasaki K, et al. Regular overtime and cardiovascular functions. Ind Health 2001; 39:244-9.

10. Schnall P, Belkic K, Landsbergis P, Schwartz J, Gerber L, Baker D, et al. Hypertension at the workplace-often an occult disease: The relevance and potential in Japan for work site surveillance? Japanese Journal of Stress Science 2000; 15:152-74.

11. Schnall P, Belkic K. Point estimates of blood pressure at the worksite. Occupational Medicine: State-of-the-Art Reviews 2000; 15:203-8.
12. Russek HI, Zohman BL. Relative significance of heredity, diet, and occupational stress in coronary heart disease of young adults. Am J Med Sci 1958; 235:266-75.

13. Theorell T, Rahe RH. Behavior and life satisfactions of Swedish subjects with myocardial infarction. J Chron Dis 1972; 25:139-47.

14. Alfredsson L, Spetz C, Theorell T. Type of occupation and near-future hospitalization for myocardial infarction and some other diagnoses. Int J Epidemiol 1985; 14:378-88.

15. Falger PRJ, Schouten EGW. Exhaustion, psychological stress in the work environment and acute myocardial infarction in adult men. J Psychosom Res 1992; 36:777-86.

16. Liu Y, Tanaka H. Overtime work, insufficient sleep, and risk of nonfatal acute myocardial infarction in Japanese men. Occup Environ Med 2002; 59: 447-51.

17. Sokejima S, Kagamimori S. Working hours as a risk factor for acute myocardial infarction in Japan: case-control study. BMJ 1998; 317:775-80.

18. Kawakami N, Araki S, Takatsuka N, Shimizu H, Ishibashi H. Overtime, psychosocial working conditions, and occurrence of non-insulin dependent diabetes mellitus in Japanese men. J Epidemiol Community Health 1999; 53:359-63.

19. Harma M. Are long work hours a health risk? Scand J Work Environ Health 2003; 29:167-9.

20. Raggatt P. Work stress among long-distance coach drivers: a survey and correlational study. Journal of Organizational Behavior 1991; 12:565-79.

21. Thorbjornsson CB, Alfredsson L, Fredriksson K, Michelsen H, Punnett L, Vingard E, et al. Physical and psychosocial factors related to low back pain during a 24-year period. A nested case-control analysis. Spine 2000; 25:369-74.

Submitted on 18/Aug/2004

Approved on 23/Aug/2004 